\title{
PEMANFAATAN LIMBAH TERNAK SEBAGAI BAHAN PEMBUATAN PUPUK BOKASHI DALAM KEGIATAN PKM TERNAK BABI RAMAH LINGKUNGAN
}

\author{
Devi Y.J.A. Moenek ${ }^{* 1}$, Novianti N. Toelle ${ }^{* 2}$ \\ *Jurusan Peternakan Program Studi Kesehatan Hewan, Politeknik Pertanian Negeri Kupang \\ Jln. Prof. Herman Yohanes Kel. Lasianan Kota Kupang NTT \\ ${ }^{1}$ deviyasintha@gmail.com \\ ${ }^{2}$. nelly_toelledyahoo.com
}

\begin{abstract}
Abstrak
Pemanfaatan limbah ternak babi menjadi pupuk bokashi bagi masyarakat membuat mereka menjadi lebih terampil dan mampu memanfaatkan limbah yang ada disekitar mereka untuk menjadi sumber pendapatan. Penerapan teknologi dilakukan melalui pelatihan dan penyuluhan pembuatan pupuk bokashi. Penyuluhan dan pelatihan mengenai pemanfaatan limbah ternak menjadi pupuk organik bokashi dilakukan di lokasi. Mitra menyediakan lahan, tenaga serta bahan-bahan yang diperlukan yang ada disekitar mereka dalam pembuatan pupuk bokashi. Mitra terlibat dan aktif dalam kegiatan yang dimaksud.
\end{abstract}

Kata kunci- bokashi, limbah ternak, Pengabdian pada masyarakat

\section{PENDAHULUAN}

Tingginya harga pupuk kimia buatan dan kelangkaan pupuk di sejumlah wilayah saat ini sangat meresahkan para petani. Sejumlah petani di beberapa daerah bahkan telah mulai melirik jenis pupuk lain sebagai pengganti pupuk kimia buatan yang biasa digunakan. Salah satu jenis pupuk yang dapat menggantikan kehadiran pupuk kimia buatan adalah bokashi.

Bokashi adalah hasil fermentasi bahan-bahan organik seperti sekam, serbuk gergajian, jerami, kotoran hewan dan lain-lain. Bahan-bahan tersebut difermentasikan dengan bantuan mikroorganisme aktivator yang mempercepat proses fermentasi. Campuran mikroorganisme yang digunakan untuk mempercepat fermentasi dikenal sebagai effective microorganism (EM). Penggunaan EM tidak hanya mempercepat proses fermentasi tetapi juga menekan bau yang biasanya muncul pada proses penguraian bahan organik. Selain itu bokashi juga terbukti meningkatkan kesuburan serta produktifitas tanaman meski efek ini baru dapat dirasakan setelah bertahuntahun penggunaan. Hal tersebut sangat wajar karena pupuk alami semacam bokashi biasanya memang mengandung unsur hara dalam dosis kecil, namun lengkap unsur makro dan mikronya.

Pengetahuan anggota kelompok mitra tentang manajemen limbah ternak belum memadai sehingga seringkali terdapat keluhan dari masyarakat sekitar kandang karena polusi yang dihasilkan dari limbah ternak babi. Padahal limbah ternak babi yang dihasilkan bisa dimanfaatkan kembali menjadi pupuk bokashi yang dapat digunakan oleh peternak dan masyarakat disekitar peternakan.
Jika dihitung secara ekonomis, dalam satu hari limbah ternak yang dihasilkan $\pm 50 \mathrm{Kg}$, dalam seminggu $\pm 350 \mathrm{Kg}$. Jika dijadikan pupuk bokashi maka dalam satu minggu bisa dihasilkan $\pm 200 \mathrm{Kg}$. Apabila pupuk tersebut dijual dengan harga Rp. 1000, maka dalam seminggu mereka bisa menghasilkan Rp. 200.000. alternatif lain yang bisa dilakukan adalah mereka menggunakan pupuk bokashi hasil pekerjaan mereka ini di lahan pertanian mereka. Sehingga mereka bisa lebih hemat dalam pembelian pupuk.

Melihat banyaknya sumber daya dan masih kurangnya pemanfaatan sumber daya tersebut oleh masyarakat di lingkungan ini, maka perlu diadakan pembinaan di bidang usaha peternakan khususnya peternakan babi, manajemen kesehatan ternak, dan penanganan limbah ternak dalam rangka mempercepat upaya peningkatan kesejahteraan masyarakat. Hal ini juga diharapkan dapat mengurangi perilaku sosial masyarakat serta budaya arus globalisasi yang mendorong masyarakat untuk berpola hidup secara konsumtif. Sehingga perilaku inovatif dan produktif dari masyarakat diharapkan dapat menumbuhkan usaha baru yang akan meningkatkan pendapatan mereka.

Kegiatan pengabdian melalui program kemitraan masyarakat tidak hanya meningkatkan pengetahuan petani dalam praktek pembuatan pupuk bokashi, tetapi juga memfasilitasi masyarakat dalam penguatan usaha kelompok dan pemasaran sehingga dapat terjadi peningkatan pendapatan untuk kesejahteraan mereka. Selain itu terjadi perubahan pola pikir yang akhirnya bisa menjadi perubahan tingkah laku dari anggota kelompok dalam usaha meningkatan taraf hidup masing-masing anggota. 
Diharapkan melalui program ini masyarakat dapat memanfaatan limbah ternak menjadi bokashi yang berorientasi pada pasar dan menguntung masyarakat.

\section{TARGET DAN LUARAN}

Jenis luaran yang menjadi target dari kegiatan ini adalah : Publikasi Ilmiah pada salah satu Jurnal Nasional dan Lokal, Leaflet berisi tentang teknologi yang diberikan kepada mitra, Meningkatnya kesejahteraan anggota kelompok, Mampu memproduksi bokashi, dan Laporan kegiatan sebagai bukti telah selesai melakukan kegiatan PKM.

\section{METODE PELAKSANAAN}

Penerapan teknologi dilakukan melalui beberapa tahapan, yaitu : a). Penyuluhan dan pelatihan mengenai pemanfaatan limbah ternak menjadi pupuk bokashi. b). Membuat demplot bokashi. c). Mitra terlibat dan aktif dalam setiap kegiatan penyuluhan, pelatihan, pendampingan, dan penerapan sesuai dengan jadwal yang sudah disepakati bersama. d). Mitra menyediakan lahan serta tenaga untuk pembuatan pupuk bokashi, e). Mitra menyediakan bahan-bahan yang diperlukan dalam pembuatan pupuk bokashi. f). Setelah selesai kegiatan maka dilakukan evaluasi terhadap anggota berupa post test dan terhadap produk yang dihasilkan berupa pemeriksaan kualitas bokashi, dan g). Keberlanjutan program akan dipantau secara periodik pada mitra terhadap produksi pupuk bokashi.

\section{IV.HASIL DAN PEMBAHASAN}

Kegiatan PKM dapat berjalan dengan baik. walaupun masih ditemukan beberapa kendala, tetapi bukan merupakan halangan yang berarti sehingga kegiatan ini dapat berlangsung dengan baik. respon dari mitra juga sangat bagus. mereka sangat antusias dengan materi yang diberikan yang terlihat dari keaktifan mereka dalam diskusi dan praktek pembuatan pupuk bokashi.

Penyuluhan dan pelatihan mengenai pemanfaatan limbah ternak menjadi pupuk organik bokashi dilakukan di lokasi. Mitra menyediakan lahan, tenaga serta bahan-bahan yang diperlukan yang ada disekitar mereka dalam pembuatan pupuk bokashi. Mitra terlibat dan aktif dalam kegiatan yang dimaksud.

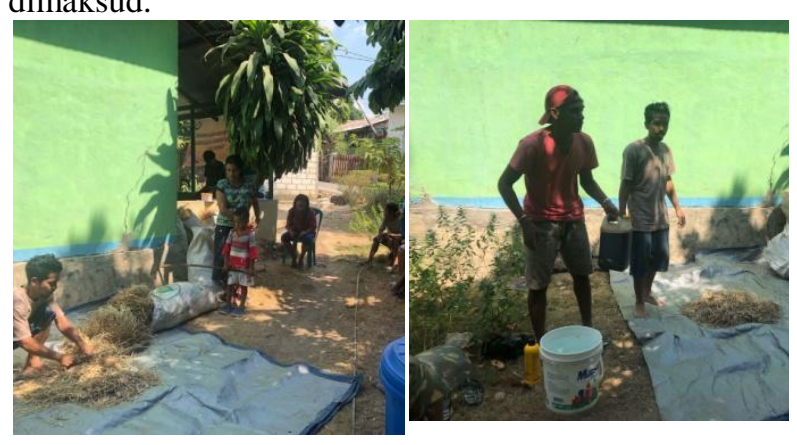

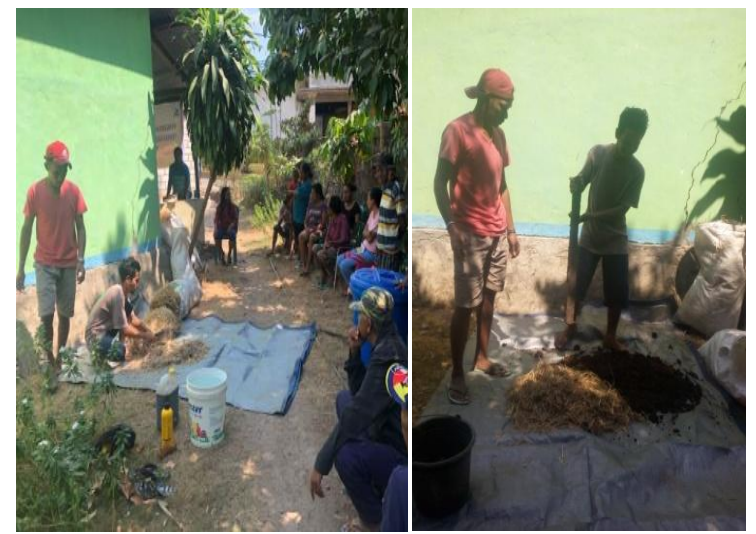

Gambar 1. Proses praktek pembuatan pupuk bokashi

\section{KESIMPULAN}

Dari kegiatan ini dapat diambil kesimpulan :

1. Penyuluhan dan pelatihan tentang pembuatan pupuk bokashi berlangsung dengan baik.

2. Ada peningkatan pengetahuan dan keterampilan mitra dalam membuat pupuk bokashi.

\section{UCAPAN TERIMAKASIH}

Ucapan terimkasih diberikan kepada Direktorat Riset dan Pengabdian pada Masyarakat Kementerian Riset Teknologi dan Pendidikan Tinggi, Politeknik Pertanian Negeri Kupang, Pusat Penelitian dan Pengabdian pada Masyarakat Politani Negeri Kupang yang mendanai kegiatan pengabdian yang dilaksanakan.

\section{DAFTAR PUSTAKA}

[1] Direktorat Budidaya Ternak, 2011, Pedoman Penataan Budidaya Ternak Babi Ramah Lingkungan

[2] Renyaan,M., 2014. Budidaya Ternak Babi Ramah Lingkungan, www.bintangpapua.com

[3] Sihombing, D.T.H., 2006. Ilmu Ternak Babi, Cetakan kedua, Gadjah Mada University Press, Yogyakarta

[4] Siregar. S.,2012. Produksi Babi, blogs.unpad.ac.id

[5] Lewar, Y., Hasan, M. and Gharu, B., 2018. PEMBERDAYAAN MASYARAKAT SONAF DAN MANEKA MELALUI KEGIATAN BETERNAK BABI PEDAGING DAN BERCOCOKTANAM JAGUNG. $J$ Dinamika, 3(1).

[6] Yuliandari, W., 2012, Cara Pembuatan Pupuk Organik, www.green.kompasiana.com 